\title{
Relationships between rumen lipopolysaccharide and mediators of inflammatory response with milk fat production and efficiency in dairy cows
}

\author{
Q. Zebeli and B. N. Ametaj ${ }^{1}$ \\ Department of Agricultural, Food and Nutritional Science, University of Alberta, Edmonton, AB, Canada T6G 2P5
}

\begin{abstract}
The main objective of this study was to evaluate correlative relationships between rumen lipopolysaccharide (LPS) and mediators of acute phase response with milk fat yield and efficiency in dairy cows challenged with graded amounts of barley grain in the diet. An additional aim of the study was to quantify the intercow variation in relation to milk fat production and acute phase response in cows fed graded amounts of grain. Eight primiparous, lactating Holstein cows (60 $\mathrm{d}$ in milk) were assigned to 1 of the 4 total mixed rations containing barley grain at $0,15,30$, and $45 \%$ (dry matter basis) in a replicated $4 \times 4$ Latin square design. Free rumen LPS, plasma acute phase proteins, and milk fat content were quantified in multiple samples collected on $\mathrm{d} 5$ and 7 of the measurement periods shortly before the morning feeding. Results showed markedly greater concentrations of rumen LPS with increasing dietary grain level. The correlative analysis revealed strong negative relationships between rumen LPS and milk fat content and yield. The predictor variable of rumen LPS explained $69 \%$ of the variation during the milk fat reduction of the cows. The stronger depression in milk fat percentage was obtained when rumen LPS exceeded a threshold of $5,564 \mathrm{ng} / \mathrm{mL}$, corresponding to a milk fat content of $3.39 \%$. The increase in concentration of rumen LPS was also associated with declines in milk fat yield and $3.5 \%$ fat-corrected milk $\left(\mathrm{R}^{2}=\right.$ $0.50)$, as well as milk energy efficiency $\left(R^{2}=0.43\right)$. The correlative analysis also indicated that the increase of plasma C-reactive protein (CRP) in response to higher grain feeding was associated with a linear decrease of milk fat content and yield $\left(\mathrm{R}^{2}=0.28\right.$ to 0.46$)$. Furthermore, the statistical analysis revealed high percentages of intercow variation related to milk fat variables, as well as the responses of rumen LPS and plasma CRP. Taken together, the current results implicate rumen LPS and the host CRP response in the lowering of milk
\end{abstract}

Received March 3, 2009.

Accepted April 9, 2009.

${ }^{1}$ Corresponding author: burim.ametaj@ualberta.ca fat content and milk energy efficiency in dairy cows fed high-grain diets. Further research is warranted to understand the mechanism(s) by which rumen LPS and inflammatory responses to LPS lower milk fat synthesis and milk energy efficiency and to develop novel strategies for their prevention.

Key words: milk fat depression, rumen lipopolysaccharide, C-reactive protein, dairy cow

\section{INTRODUCTION}

It has long been recognized that when dairy cows are fed high-concentrate/low-forage $(\mathbf{H C} / \mathbf{L F})$ diets or diets rich in plant-oil supplements containing high amounts of polyunsaturated fatty acids (FA), there is a reduction in milk fat content, a syndrome commonly referred to as milk fat depression (MFD). The latter disorder has been in the focus of dairy scientists for over a century, with multiple hypotheses being advanced to explain the causes of diet-induced MFD (Davis and Brown, 1970).

Although our knowledge about the causes of MFD has increased tremendously during the last decades, most of the postulates proposed during the years have not fully explained the etiology of MFD (Bauman et al., 2008). One of the hypotheses that has gained the most support recently is that of ruminal biohydrogenation byproducts of long-chain unsaturated FA (Bauman and Griinari, 2001). It was Davis and Brown (1970) who first reported a negative correlation between changes in milk fat yield and concentrations of trans FA in the milk. This finding triggered extensive research during the last decades focused predominantly on the interrelationships between rumen biohydrogenation of dietary polyunsaturated FA and mammary synthesis of FA (Bauman et al., 2008).

In most investigations involving plant oil-induced MFD, the trans-10, cis-12-18:2, an intermediate of the rumen biohydrogenation process, has been identified as a potent suppressor of milk fat synthesis (Davis and Brown, 1970). However, during diet-induced MFD, the amount of trans-10, cis-12-18:2 in the milk and the magnitude of reduction in milk fat yield do not align 
with the dose-response curve generated with abomasal infusion of this isomer (Piperova et al., 2004; Bauman et al., 2008). This has led several investigators to propose that other rumen unidentified biohydrogenation isomers or products might be involved in the biology of MFD (Piperova et al., 2004; Bauman et al., 2008).

Another interesting line of investigation has indicated that feeding dairy cows diets rich in readily digestible carbohydrates and low in fiber is associated with the release of large amounts of LPS, a cell-wall component of all gram-negative bacteria, in the rumen fluid (Gozho et al., 2007; Emmanuel et al., 2008; Khafipour et al., 2009). It has been increasingly recognized that LPS stimulates the release of proinflammatory cytokines such as tumor necrosis factor (TNF)- $\alpha$, IL-1, and IL-6 by liver macrophages, which in turn activate hepatocytic receptors and initiate the synthesis of acute phase proteins (APP; Sweet and Hume, 1996). The LPS also modulates lipid metabolism in different body tissues. For example, pieces of evidence pinpoint suppressive effects of LPS on key enzymes related to de novo FA synthesis such as FA synthetase and acetyl-CoA carboxylase (Pekala et al., 1983; López-Soriano and Williamson, 1994) in the mammary gland and down regulation of lipoprotein lipase (LPL) activity (Khovidhunkit et al., 2004). The latter enzyme plays a key role in clearance of circulating triglyceride (TAG)-rich chylomicrons and very low density lipoprotein (VLDL) as a host defense mechanism to decrease LPS toxicity (Feingold et al., 1992) and is involved in the uptake of FA for incorporation into milk fat (Merkel et al., 2002). Recently, the LPS released in the gastrointestinal tract during feeding of high-grain or high-fat diets has been implicated in the etiology of multiple energy- and lipidrelated metabolic disturbances in ruminants (Andersen, 2003; Ametaj et al., 2005), rodents, and humans (Cani et al., 2007; Amar et al., 2008). Nevertheless, the interrelationships between rumen LPS and the host immune responses to LPS during feeding of $\mathrm{HC} / \mathrm{LF}$ diets with lipid metabolism in the mammary tissue have not yet been established. Based on the aforementioned facts, we hypothesized that free LPS released in the rumen in response to high-grain feeding and its resulting mediators of inflammatory response in plasma might be involved in altering milk fat production and milk energy efficiency in lactating Holstein cows.

To test our hypothesis, we fed lactating dairy cows graded amounts of barley grain and evaluated the relationships between rumen LPS and plasma APP with variables of milk fat production. An additional aim of the study was to quantify the intercow variation in relation to milk production and acute phase response in cows fed graded amounts of grain.

\section{MATERIALS AND METHODS}

\section{Animals, Diets, and Experimental Design}

All experimental procedures were approved by the University of Alberta Animal Care and Use Committee for Livestock, and cows were cared for in accordance with the guidelines of the Canadian Council on Animal Care (1993). Because the variables related to rumen LPS and plasma APP have been reported previously (Emmanuel et al., 2008), this article has mainly focused on the effect of diet on milk fat production and efficiency, as well as on the correlative relationships between rumen LPS and plasma APP with milk fat production variables. Eight ruminally cannulated ( $\varnothing 100$ mm, Bar Diamond, Parma, ID) primiparous Holstein cows were used in this study in a replicated $4 \times 4$ Latin square design. The experimental period was $21 \mathrm{~d}$, with the first $11 \mathrm{~d}$ used for diet adaptation. At the start of the experiment, the cows were at $60 \pm 15 \mathrm{~d}$ (mean $\pm \mathrm{SD}$ ) postpartum. The cows were housed in tie stalls with free access to water and fed once daily at $0800 \mathrm{~h}$ and milked twice at 0500 and $1600 \mathrm{~h}$. To challenge the cows with graded amounts of rumen-fermentable carbohydrates in their diets, a basic ration was supplemented with 0 , 15,30 , or $45 \%$ (DM basis) barley grain to provide the 4 dietary treatments, which varied from 35.4 to $45.5 \%$ in the total content of NFC. The amount of grain in the diet was stepped up or down during the adaptation period. Daily ration was offered as TMR for ad libitum intake to allow about $5 \%$ feed refusals. Diets were formulated to meet or exceed the nutrient requirements of a 680-kg lactating cow as per NRC (2001) guidelines. Ingredients and nutrient composition of the TMR are presented in Table 1.

\section{Sample and Data Collection}

Blood samples were collected from the coccygeal vein shortly before the morning feeding using $10-\mathrm{mL}$ vacutainer tubes (Becton Dickinson, Franklin Lake, NJ) containing sodium heparin anticoagulant. Blood samples were stored in ice and centrifuged within 20 min at $4^{\circ} \mathrm{C}$ for $20 \mathrm{~min}$ at $3,000 \times g$ to separate plasma (Rotanta $460 \mathrm{R}$, Hettich Zentrifugan, Tuttlingen, Germany). Plasma samples were stored at $-20^{\circ} \mathrm{C}$ until their analysis.

Feed intake was measured by the difference from feed refusals, which were weighed back daily at about 0700 h. Milk samples were collected at 0500 and $1600 \mathrm{~h}$ on d 5 and 7 of each experimental period. Milk fat content was measured with mid-infrared spectroscopy (MilkoScan 605, A/S N Foss Electric, Hillerød, Denmark) by Central Milk Testing Laboratory in Edmonton-Alberta. 
Table 1. Ingredients and nutrient composition of the four experimental total mixed rations differing in the level of barley inclusion

\begin{tabular}{|c|c|c|c|c|}
\hline Item & $0 \%$ barley & $15 \%$ barley & $30 \%$ barley & $45 \%$ barley \\
\hline \multicolumn{5}{|l|}{ Ingredients (\% of DM) } \\
\hline Alfalfa hay & 15.0 & 15.0 & 15.0 & 15.0 \\
\hline Alfalfa silage & 12.0 & 12.0 & 12.0 & 12.0 \\
\hline Barley silage & 58.0 & 43.0 & 28.0 & 13.0 \\
\hline Rolled barley & 0.00 & 15.0 & 30.0 & 45.0 \\
\hline Gluten meal & 6.00 & 6.00 & 6.00 & 6.00 \\
\hline Fish meal & 1.03 & 1.03 & 1.03 & 1.03 \\
\hline Canola meal & 0.98 & 0.98 & 0.98 & 0.98 \\
\hline Dairy premix ${ }^{1}$ & 0.58 & 0.58 & 0.58 & 0.58 \\
\hline Megalac $^{2}$ & 1.79 & 1.79 & 1.79 & 1.79 \\
\hline Limestone & 0.58 & 0.58 & 0.58 & 0.58 \\
\hline Biofos $^{3}$ & 0.40 & 0.40 & 0.40 & 0.40 \\
\hline Magnesium oxide & 0.35 & 0.35 & 0.35 & 0.35 \\
\hline Sodium bicarbonate & 0.76 & 0.76 & 0.76 & 0.76 \\
\hline Vitamin $\mathrm{E}^{4}$ & 0.09 & 0.09 & 0.09 & 0.09 \\
\hline Vitamin $\mathrm{D}_{3}{ }^{5}$ & 0.17 & 0.17 & 0.17 & 0.17 \\
\hline Molasses & 0.35 & 0.35 & 0.35 & 0.35 \\
\hline Hydrogenated tallow & 1.87 & 1.87 & 1.87 & 1.87 \\
\hline \multicolumn{5}{|c|}{ Nutrient composition (\% of DM unless otherwise stated) } \\
\hline ME (Mcal/kg of DM) & 2.45 & 2.42 & 2.40 & 2.39 \\
\hline $\mathrm{CP}$ & 16.2 & 16.4 & 16.5 & 16.7 \\
\hline $\mathrm{NDF}$ & 32.8 & 30.2 & 27.6 & 25.0 \\
\hline $\mathrm{ADF}$ & 21.8 & 19.4 & 17.0 & 14.6 \\
\hline $\mathrm{NFC}^{6}$ & 35.4 & 38.8 & 42.1 & 45.5 \\
\hline $\mathrm{Ca}$ & 1.30 & 1.30 & 1.20 & 1.20 \\
\hline $\mathrm{P}$ & 0.40 & 0.40 & 0.50 & 0.50 \\
\hline DCAD (mEq/kg) & 300 & 274 & 248 & 223 \\
\hline
\end{tabular}

${ }^{1}$ Contained calcium, 0.1\%; phosphorous, $0.6 \%$; sodium, $11.5 \%$; magnesium, $0.3 \%$; potassium, $0.7 \%$; sulfur, $0.23 \%$; zinc, $5,000 \mathrm{mg} / \mathrm{kg}$; copper, $1,170 \mathrm{mg} / \mathrm{kg}$; manganese, $3,100 \mathrm{mg} / \mathrm{kg}$; iodine, $80 \mathrm{mg} / \mathrm{kg}$; cobalt, $6.2 \mathrm{mg} /$ $\mathrm{kg}$; vitamin A, 1,265,000 IU/kg; vitamin D, 142,000 IU $/ \mathrm{kg}$; vitamin E, 3,800 IU $/ \mathrm{kg}$.

${ }^{2}$ Contained $85 \%$ fat as fatty acids and $9.6 \%$ calcium with a $\mathrm{NE}_{\mathrm{L}}$ of $6.52 \mathrm{Mcal} / \mathrm{kg}$.

${ }^{3}$ Contained monocalcium phosphate and dicalcium phosphate in a ratio of $2: 1$.

${ }^{4}$ Contained $5,000 \mathrm{IU} / \mathrm{kg}$.

${ }^{5}$ Contained 500,000 IU $/ \mathrm{kg}$.

${ }^{6} \mathrm{NFC}=100-(\%$ ash $+\% \mathrm{CP}+\% \mathrm{NDF}+\%$ ether extracts $)$.

To evaluate the effects of dietary grain challenge on the production response of the cows, data of DMI, actual milk yield, 3.5\% FCM, and milk fat yield were used. Because fat is the major energy component in milk, and other milk components usually respond less to a highgrain diet, milk energy efficiency (MEE), expressed as grams of milk fat produced per kilogram of DMI, was calculated and served to evaluate the effects of dietary treatment on energy efficiency of the cows.

Samples from rumen fluid $(100 \mathrm{~mL})$ were obtained at $0,2,4,6,8,10$, and $12 \mathrm{~h}$ after the morning feeding on the last day of each period, as well as at $0 \mathrm{~h}$ on $\mathrm{d} 5$ and 7 . All rumen fluid samples were collected through the cannula using a tube fitted with a strainer and a syringe into a $140-\mathrm{mL}$ plastic container. The $\mathrm{pH}$ of rumen fluid was determined immediately by a mobile $\mathrm{pH}$ meter (Accumet AP61, Fisher Scientific, Ottawa, Ontario, Canada). The rumen fluid samples obtained at $0 \mathrm{~h}$ on $\mathrm{d}$ 5 and 7 of each experimental period were centrifuged at $6,000 \times g$ for $15 \mathrm{~min}$, and the supernatant was stored at $-20^{\circ} \mathrm{C}$ until being analyzed for LPS content. The LPS content was determined in preprandial ruminal fluid to evaluate relationships of rumen LPS with milk parameters at a time when the activity of rumen microbiota is believed to be more stable than after feeding.

\section{Sample Analyses}

Determination of the concentrations of cell-free LPS in the rumen fluid supernatant by the pyrochrome Limulus amebocyte lysate assay has been described previously (Emmanuel et al., 2008). In brief, $10 \mathrm{~mL}$ of rumen fluid samples was centrifuged at $6,000 \times g$ for $15 \mathrm{~min}$, and the supernatant was stored at $-20^{\circ} \mathrm{C}$. For use in the assay, $1.5 \mathrm{~mL}$ of the supernatant was centrifuged again at $10,000 \times g$ for $30 \mathrm{~min}$. The supernatant was then passed through a disposable $0.22-\mu \mathrm{m}$ sterile, pyrogen-free filter (Fisher Scientific, Fairlawn, NJ) and diluted 1,000-fold using pyrogen-free Limulus amebocyte lysate reagent water and pyrogen-free test 
tubes (Associates of Cape Cod Inc., East Falmouth, MA). Control standard LPS containing $10 \mathrm{ng}$ of LPS per vial (Associates of Cape Cod Inc.) was used to prepare the standard solutions. Samples were tested in duplicate, and the optical density values were read on a microplate spectrophotometer (Spectramax 190, Molecular Devices Corporation, Sunnyvale, CA) at a wavelength of $405 \mathrm{~nm}$.

Quantitative determination of the concentrations of plasma APP such as C-reactive protein (CRP), serum amyloid A, LPS-binding protein, and haptoglobin using ELISA kits has been described in details by Emmanuel et al. (2008).

\section{Statistical Analyses}

Data were analyzed using the MIXED procedure of SAS (version 9.1.3, 2006; SAS Institute Inc., Cary, NC) according to the following model:

$$
Y_{i j k l m n}=\mu+p_{i}+a_{j}+a(s)_{j k}+d_{l}+t_{m}+e_{i j k l m n},
$$

where $Y_{i j k l m n}$ is the observation $n$ of dependent variables, $\mu$ represents the population mean, $p_{i}$ is the fixed effect of period $i$ ( $i=1$ to 4$), a_{j}$ is the fixed effect of cow $j$ $(j=1$ to 8$), a(s)_{j k}$ is the random effect of cow $j$ within the square $k(k=1$ to 2$), d_{l}$ is the random effect of measurement day $l(l=1$ to 2$)$ considered as repeated measures with a compound symmetry covariance structure, $t_{m}$ represents the fixed effect of treatment $m(m$ $=1$ to 4 ), and $e_{i j k l m n}$ is the residual error assumed to be normally distributed. To test linear or quadratic effects of treatment on all response variables, the orthogonal contrasts with the CONTRAST statement of SAS were used. Significance was declared at $P \leq 0.05$, and the tendency was considered up to $0.05<P \leq 0.10$.

To assess the extent to which the variation in the response variables was explained by the individual cow or period effects, differences in residuals between the full statistical model described earlier and models in which the variable cow or period were omitted were used. Relationships between explanatory variables and milk fat responses were tested by the MIXED procedure of SAS and quantified using the option SOLUTION, as well as by fitting different straight-line, single or double breakpoint, nonlinear models with the NLMIXED procedure of SAS (Robbins et al., 2006), accounting for interanimal variation and the effect of period. Only significant relationships $(P<0.05)$ were quantified and presented in this article. Root mean square error, $P$-value, and the determination coefficient $\left(\mathrm{R}^{2}\right)$ were computed and used to evaluate the goodness of the fit. Graphical depiction of the relationships obtained was conducted with the GPLOT procedure of SAS.

\section{RESULTS}

\section{Cows' Responses to Graded Amounts of Grain in the Diet}

Outcomes of the ANOVA regarding different responses of the cows challenged with graded amounts of barley grain in the diet are given in Table 2. Results showed a linear increase in DMI and milk yield with an increase in the proportion of barley grain in the diet $(0,15,30$, and $45 \%)$. In contrast, milk fat variables including milk fat content, milk fat yield, and 3.5\% FCM, as well as MEE, linearly decreased as the amount of barley grain in the diet increased. Diet also affected ruminal $\mathrm{pH}$ in a quadratic fashion (Table 2).

Results also demonstrated a clear effect of the level of dietary grain on concentration of LPS in the rumen fluid, as well as on plasma and milk fat variables (Table 2 ). Overall data indicated that cows fed the $45 \%$ grain diet had 10- to 12 -fold greater LPS than cows fed 0 or $15 \%$ grain rations. In addition, all acute phase proteins measured in plasma, including CRP, serum amyloid A, and LPS-binding protein, increased with enhancement of the amount of grain in the diet.

Data showing the individual cow effect or period effect on variation of response variables measured are given in Table 3. Results indicated that milk fat variables were affected by both individual cow and period. Furthermore, period-related variations ranged from 18.1 to $30.5 \%$. The statistical analysis indicated that 36.4 and $54.4 \%$ of the variation for rumen LPS and plasma CRP, respectively, belong to the cow effect, whereas the variation of $16.8 \%$ for rumen $\mathrm{pH}$ response was related to the period effect.

\section{Relationships Between Rumen LPS, Plasma CRP, and Milk Fat Yield}

The double break-point model, which fit best to the data of milk fat content in response to rumen LPS, showed that concentration of LPS in the rumen fluid was negatively correlated with milk fat content (Figure 1). This predictor variable explained $69 \%$ of the variation of milk fat decrease in cows fed graded levels of barley grain. As demonstrated by the derived equation in Figure 1, the first decrease in milk fat content, from 3.89 to $3.48 \%$, was observed when the concentration of free rumen LPS reached $900 \mathrm{ng} / \mathrm{mL}$; however, the decline in milk fat percentage was minimal as long as rumen LPS did not exceed a threshold of $5,564 \mathrm{ng} /$ $\mathrm{mL}$, corresponding to a milk fat content of $3.39 \%$. A stronger linear depression of milk fat content was found when rumen concentration of LPS exceeded the latter threshold (Figure 1). 
Table 2. The responses of milk production, milk energy efficiency, and rumen fluid variables as well as the variables related to plasma mediators of acute phase response in lactating dairy cows fed graded amounts of barley grain

\begin{tabular}{|c|c|c|c|c|c|c|c|}
\hline \multirow[b]{2}{*}{ Parameter } & \multicolumn{4}{|c|}{ Barley grain in the diet } & \multirow[b]{2}{*}{ SEM } & \multicolumn{2}{|c|}{$P$-value ${ }^{1}$} \\
\hline & $0 \%$ & $15 \%$ & $30 \%$ & $45 \%$ & & Linear & Square \\
\hline \multicolumn{8}{|l|}{ Milk efficiency variables } \\
\hline Milk yield (kg/d) & 27.4 & 28.0 & 28.9 & 31.2 & 0.72 & $<0.01$ & NS \\
\hline Milk fat content $(\%)$ & 3.66 & 3.50 & 3.19 & 2.90 & 0.09 & $<0.01$ & NS \\
\hline Fat yield $(\mathrm{kg} / \mathrm{d})$ & 0.98 & 0.97 & 0.91 & 0.89 & 0.03 & 0.04 & NS \\
\hline \multicolumn{8}{|l|}{ Rumen fluid variables ${ }^{3}$} \\
\hline Mean ruminal $\mathrm{pH}$ & 6.44 & 6.22 & 6.23 & 6.25 & 0.06 & 0.07 & 0.05 \\
\hline Lowest ruminal $\mathrm{pH}$ & 6.23 & 5.91 & 5.86 & 5.99 & 0.09 & 0.09 & 0.04 \\
\hline Rumen fluid $\mathrm{LPS}^{4}$ (ng/mL) & 781 & 889 & 4,914 & 8,880 & 491 & $<0.01$ & $<0.01$ \\
\hline \multicolumn{8}{|c|}{ Plasma acute phase proteins ${ }^{5}(\mu \mathrm{g} / \mathrm{mL})$} \\
\hline C-reactive protein & 1.10 & 1.11 & 1.17 & 1.42 & 0.04 & $<0.01$ & 0.02 \\
\hline Serum amyloid A & 10.4 & 5.8 & 19.1 & 32.8 & 4.37 & $<0.01$ & 0.04 \\
\hline
\end{tabular}

${ }^{1}$ Linear or quadratic effects of dietary barley grain inclusion.

${ }^{2} \mathrm{MEE}=$ milk energy efficiency; calculated as the amount of milk fat produced per each kilogram of DM ingested.

${ }^{3}$ Mean ruminal $\mathrm{pH}$ from measurements of $\mathrm{pH}$ at $0,2,4,8,10$, and $12 \mathrm{~h}$ after the morning feeding; lowest ruminal $\mathrm{pH}$ readings measured from 0 to $12 \mathrm{~h}$ after the morning feeding.

${ }^{4}$ Lipopolysaccharide concentration in the rumen fluid collected at 2 different days shortly before the morning feeding $(0 \mathrm{~h})$.

${ }^{5}$ Concentration of acute phase proteins in the plasma measured at 2 different days shortly before the morning feeding $(0 \mathrm{~h})$.

The increase in concentration of rumen LPS was also associated with a decline in both milk fat yield and $3.5 \%$ FCM $\left(\mathrm{R}^{2}=0.50, P<0.001\right)$. As shown in Figure 2, the increase in concentration of rumen LPS, particularly within the range of 6,574 to $8,000 \mathrm{ng} / \mathrm{mL}$, strongly decreased milk fat yield and $3.5 \%$ FCM. After the threshold of $8,000 \mathrm{ng} / \mathrm{mL}$, the analysis indicated no further decline and, hence, no response of both variables, revealing plateau values of 0.77 and $22.3 \mathrm{~kg} / \mathrm{d}$ milk fat yield and 3.5\% FCM, respectively.
The association between concentration of rumen LPS and MEE is shown in Figure 3. The straight-line, single break-point model, which fit best to the response of MEE to rumen LPS, indicated that the increase of rumen LPS is associated with a lower milk efficiency of the dairy cows. Moreover, cows linearly decreased (slope $=-0.0028$, root mean square error $=9.41, \mathrm{R}^{2}=$ $0.43, P<0.001)$ their MEE when concentration of LPS in the rumen exceeded $3,320 \mathrm{ng} / \mathrm{mL}$, the estimated threshold value of rumen LPS.

Table 3. Significance of effects of period and cow and their percentage of variation ${ }^{1}$ for selected response parameters

\begin{tabular}{|c|c|c|c|c|}
\hline \multirow[b]{2}{*}{ Parameter $^{2}$} & \multicolumn{2}{|c|}{$P$-value } & \multicolumn{2}{|c|}{ Variation in $\%$} \\
\hline & Period & Cow & Period & Cow \\
\hline \multicolumn{5}{|l|}{ Milk efficiency variables } \\
\hline Milk yield (kg/d) & 0.06 & $<0.01$ & 18.1 & 49.3 \\
\hline Milk fat content (\%) & 0.01 & $<0.01$ & 30.5 & 43.0 \\
\hline Milk fat yield $(\mathrm{kg} / \mathrm{d})$ & NS & $<0.01$ & - & 41.4 \\
\hline $3.5 \%$ FCM $(\mathrm{kg} / \mathrm{d})$ & NS & $<0.01$ & - & 43.2 \\
\hline \multicolumn{5}{|l|}{ Ruminal fluid variables } \\
\hline Mean ruminal $\mathrm{pH}^{3}$ & 0.07 & NS & 16.8 & - \\
\hline Rumen $\operatorname{LPS}^{4}(\mathrm{ng} / \mathrm{mL})$ & NS & 0.05 & - & 36.4 \\
\hline Plasma C-reactive protein $(\mu \mathrm{g} / \mathrm{mL})$ & NS & $<0.01$ & - & 54.4 \\
\hline
\end{tabular}

${ }^{1}$ Calculated as difference in residuals between the full statistical model (period, individual cow, and treatment as explanatory variables) and a statistical model in which the effects of period and cow were not considered.

${ }^{2}$ Only parameters for which at least one factor had a $P<0.10$ are shown.

${ }^{3}$ Mean ruminal $\mathrm{pH}$ from measurements of $\mathrm{pH}$ at $0,2,4,8,10$, and $12 \mathrm{~h}$ after the morning feeding.

${ }^{4}$ Lipopolysaccharide concentration in the rumen fluid collected shortly before the morning feeding $(0 \mathrm{~h})$.

$\mathrm{NS}=P>0.10$. 


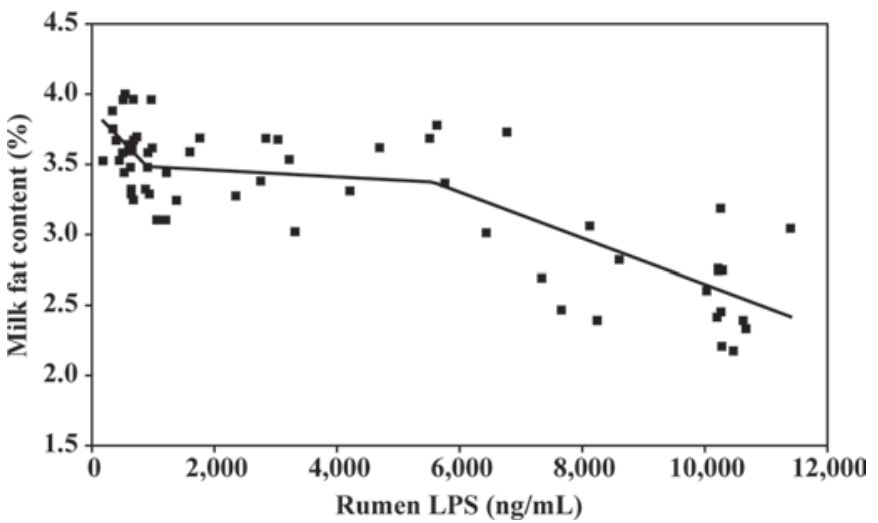

Figure 1. Double break-point model fitted to milk fat content data $(y)$ in response to concentration of LPS $(x)$ in the rumen fluid of dairy cows fed graded amounts of barley grain: $y=\mathrm{a}_{0}+\mathrm{b}_{1} \times x$, if $x \leq \mathrm{R}_{1} ; y$ $=\mathrm{a}_{0}+\mathrm{b}_{1} \times \mathrm{R}_{1}+\mathrm{b}_{2} \times\left(x-\mathrm{R}_{1}\right)$, if $\mathrm{R}_{2} \geq x>\mathrm{R}_{1} ; y=\mathrm{a}_{0}+\mathrm{b}_{1} \times \mathrm{R}_{1}+\mathrm{b}_{2}$ $\times\left(\mathrm{R}_{2}-\mathrm{R}_{1}\right)+\mathrm{b}_{3} \times\left(x-\mathrm{R}_{2}\right)$, if $x>\mathrm{R}_{2}\left(\mathrm{a}_{0}=3.89, \mathrm{~b}_{1}=-0.00045, \mathrm{~b}_{2}=\right.$ $-0.00002, b_{3}=-0.00016, R_{1}$ (first break point) $=900 \mathrm{ng} / \mathrm{mL}$ rumen LPS, $\mathrm{R}_{2}$ (second break point) $=5,564 \mathrm{ng} / \mathrm{mL}$ rumen LPS); root mean square error $=0.28, \mathrm{R}^{2}=0.69, P<0.001, \mathrm{n}=64$.

The quantification of the response of milk fat content to plasma CRP is given in Figure 4. The increase of CRP in the plasma greater than a threshold value of $0.96 \mu \mathrm{g} / \mathrm{mL}$ resulted in a linear decrease (slope $=$ -0.853 ) of milk fat content. Thus, the analysis revealed that milk fat content did not respond (asymptotic plateau $=3.57 \%$ milk fat) to plasma CRP as long as its concentration was lower than the threshold value of $0.96 \mu \mathrm{g} / \mathrm{mL}$.

The responses of milk fat yield and $3.5 \%$ FCM to plasma CRP were linear, whereby plasma CRP explained 45 and $46 \%$ of the variation of milk fat yield and $3.5 \%$ FCM, respectively (Figure 5). Estimations indicated that an increase of plasma CRP of $0.1 \mu \mathrm{g} / \mathrm{mL}$ is associated with a decrease in milk fat yield and $3.5 \%$ FCM of about 24 and $670 \mathrm{~g} / \mathrm{d}$, respectively.

\section{DISCUSSION}

\section{Relationships Between Rumen LPS, Plasma CRP, and Milk Fat Yield}

This article addresses the hypothesis that LPS, released from gram-negative bacteria in the rumen fluid when cows are fed $\mathrm{HC} / \mathrm{LF}$ diets, and plasma mediators of the inflammatory response against LPS are associated with MFD syndrome. The plausibility of this hypothesis is derived from several previous observations that suggest LPS and inflammatory responses to LPS might be related to MFD. First, several investigators, including our team, have shown that feeding cattle $\mathrm{HC}$ / LF diets is associated with major changes in the gastrointestinal microbiota in favor of gram-negative bacteria
(Krause et al., 2003), resulting in a notably greater concentration of LPS in the rumen fluid (Gozho et al., 2007; Emmanuel et al., 2008). Second, we and others demonstrated that LPS is able to permeate rumen and colon tissues at concentrations similar to those found during feeding of HC/LF diets (Emmanuel et al., 2007; Khafipour et al., 2009). Third, intramammary infusion of LPS in dairy cows and intraperitoneal administration of LPS in lactating rats decreases lipogenesis in the mammary gland (Shuster et al., 1991; López-Soriano and Williamson, 1994). Fourth, mediators of inflammatory response against LPS, such as TNF- $\alpha$ and IL-1 when injected intravenously, suppress milk fat production and LPL activity in the mammary gland (Evans and Williamson, 1988; Argilés et al., 1989).

To test our hypothesis, we conducted correlative analyses of data related to concentration of LPS in the rumen fluid and plasma APP with milk fat con-
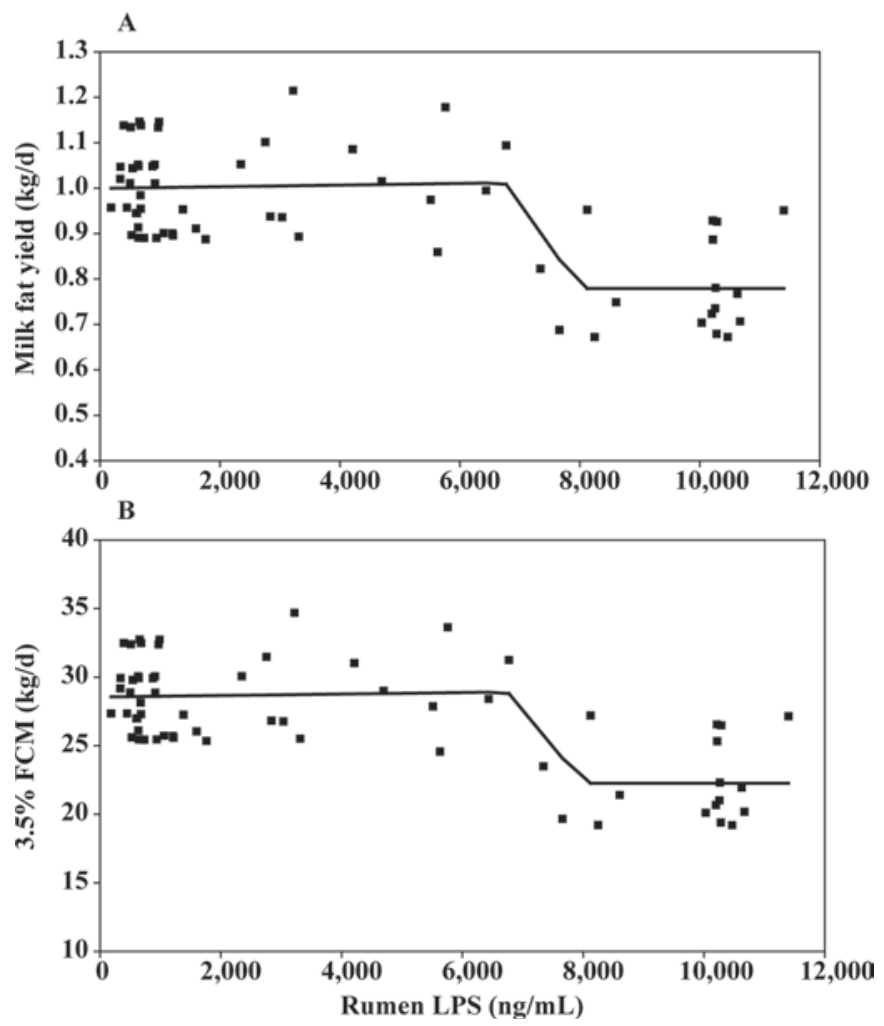

Figure 2. Double break-point models fitted to data of milk fat yield (A) or 3.5\% FCM (B), both expressed as $y$, in response to concentration of LPS $(x)$ in rumen fluid of dairy cows fed graded amounts of barley grain: $\mathrm{A}, y=\mathrm{a}_{0}+\mathrm{b}_{1} \times x$, if $x \leq \mathrm{R}_{1} ; y=\mathrm{a}_{0}+\mathrm{b}_{1} \times \mathrm{R}_{1}+\mathrm{b}_{2}$ $\times\left(x-\mathrm{R}_{1}\right)$, if $\mathrm{R}_{2} \geq x>\mathrm{R}_{1}\left(\mathrm{a}_{0}=0.99, \mathrm{~b}_{1}=0.0000018, \mathrm{~b}_{2}=-0.00019\right.$, $\mathrm{R}_{1}$ (first break point) $=6,574 \mathrm{ng} / \mathrm{mL}$ rumen LPS, $\mathrm{R}_{2}$ (second break point) $=8,000 \mathrm{ng} / \mathrm{mL}$ rumen LPS); root mean square error $=0.098$, $\mathrm{R}^{2}=0.50, P<0.001, \mathrm{n}=64 ; \mathrm{B}, y=\mathrm{a}_{0}+\mathrm{b}_{1} \times x$, if $x \leq \mathrm{R}_{1} ; y=\mathrm{a}_{0}+$ $\mathrm{b}_{1} \times \mathrm{R}_{1}+\mathrm{b}_{2} \times\left(x-\mathrm{R}_{1}\right)$, if $\mathrm{R}_{2} \geq x>\mathrm{R}_{1}\left(\mathrm{a}_{0}=28.55, \mathrm{~b}_{1}=0.000054, \mathrm{~b}_{2}\right.$ $=-0.0053, \mathrm{R}_{1}=6,749 \mathrm{ng} / \mathrm{mL}$ rumen LPS, $\mathrm{R}_{2}=8,000 \mathrm{ng} / \mathrm{mL}$ rumen LPS); root mean square error $=2.81, \mathrm{R}^{2}=0.50, P<0.001, \mathrm{n}=64$. 


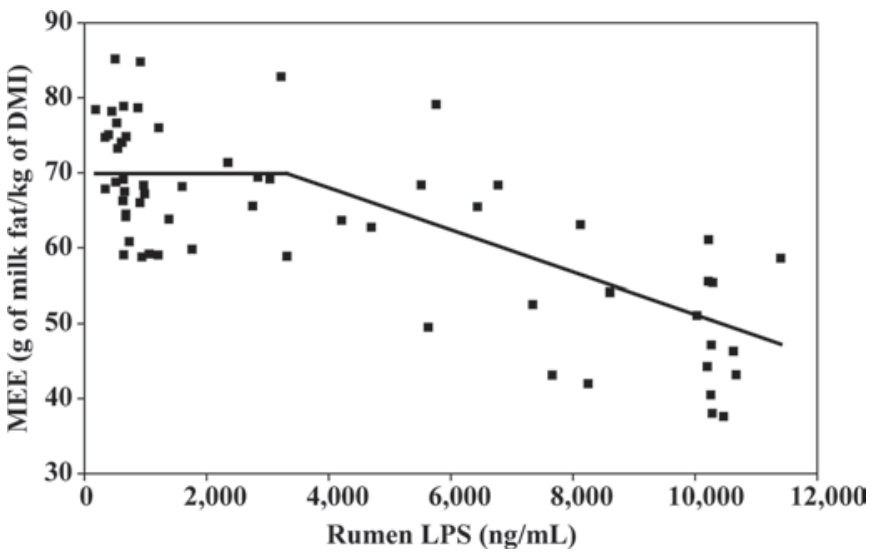

Figure 3. A straight-line, single break-point model fitted to milk energy efficiency (MEE, $y$ ) in response to the concentration of LPS $(x)$ in the rumen fluid of dairy cows fed graded amounts of barley grain: $y$ $=\mathrm{a}_{0}+\mathrm{b}_{1} \times x$, if $x>\mathrm{R}\left(\mathrm{a}_{0}=79.2, \mathrm{~b}_{1}=-0.0028, \mathrm{R}\right.$ (break point) $=$ $3,328 \mathrm{ng} / \mathrm{mL}$ rumen LPS, asymptotic plateau of $y=69.9)$; root mean square error $=9.41, \mathrm{R}^{2}=0.43, P<0.001, \mathrm{n}=64$.

tent and yield, 3.5\% FCM, and MEE during feeding of graded amounts of barley grain to dairy cows. Our results provide evidence of strong negative correlations of free rumen LPS with milk fat production and MEE. Interestingly, changes in the absolute content of milk fat were shown to be more responsive to rumen LPS than changes in milk fat yield and $3.5 \%$ FCM, whose effect on the latter variables was balanced also by an inconsistent daily milk yield of the cows. In addition to the already published evidence indicating a decline in milk fat content after intramammary or intraperitoneal administration of LPS (Shuster et al., 1991; López-Soriano and Williamson, 1994), our study is the first to pinpoint the presence of relationships of rumen LPS with milk fat yield and efficiency in dairy cows fed graded amounts of barley grain.

Although the mechanism by which LPS enters the host's internal fluids is not clear, our previous in vitro research demonstrated that LPS from Escherichia coli O55:B5 was able to permeate rumen and colon tissues independently of medium pH (Emmanuel et al., 2007). In support of this postulate, Khafipour et al. (2009) demonstrated enhanced plasma LPS in dairy cows during a grain-based SARA challenge. Other research has also indicated that LPS uses both transcellular and paracellular pathways and its toll-like receptor- 4 to translocate into the portal blood and lymphatic fluid (Neal et al., 2006). Interestingly, Ghoshal et al. (2009) demonstrated that LPS is transported into blood circulation by a mechanism facilitated by long-chain FA (e.g., oleic acid) and chylomicron formation from epithelial intestinal cells.

Although the mechanistic details relating rumen LPS and plasma mediators of inflammatory response with milk fat production are not currently clear, it is speculated that LPS might affect milk fat synthesis indirectly through the release of proinflammatory cytokines from local macrophages into blood circulation. It is known that LPS triggers secretion of proinflammatory cytokines TNF- $\alpha$ and IL-1 by immune cells (Sweet and Hume, 1996). Furthermore, several studies have indicated that intraperitoneal infusion of LPS or intravenous administration of TNF- $\alpha$ or IL-1 notably lower lipogenesis in the mammary gland of lactating rats (Argilés et al., 1989; López-Soriano and Williamson, 1994). In addition, TNF- $\alpha$ was shown to inhibit the activity of LPL, the key enzyme involved in releasing glycerol and NEFA from circulating lipoproteins for mammarygland uptake (Argilés et al., 1989). In addition, LPS was reported to induce mediators that inhibit the activity of key enzymes related to de novo FA synthesis such as FA synthetase and acetyl-CoA carboxylase (Pekala et al., 1983; López-Soriano and Williamson, 1994).

Another interesting finding of our investigation was the negative correlation between plasma CRP and milk fat production. To our best knowledge, this is the first report to indicate an association between plasma CRP and milk fat content. In contrast to the strong relationship with CRP, the milk fat variables correlated poorly to other plasma APP measured, such as serum amyloid A, LPS-binding protein, and haptoglobin. The reason for a differential response of milk fat yield to the APP during the feeding of graded amounts of grain is not currently well understood. Although the exact underlying mechanisms between CRP and milk fat synthesis are not yet known, the strong negative relationships of plasma CRP and milk fat variables are not surpris-

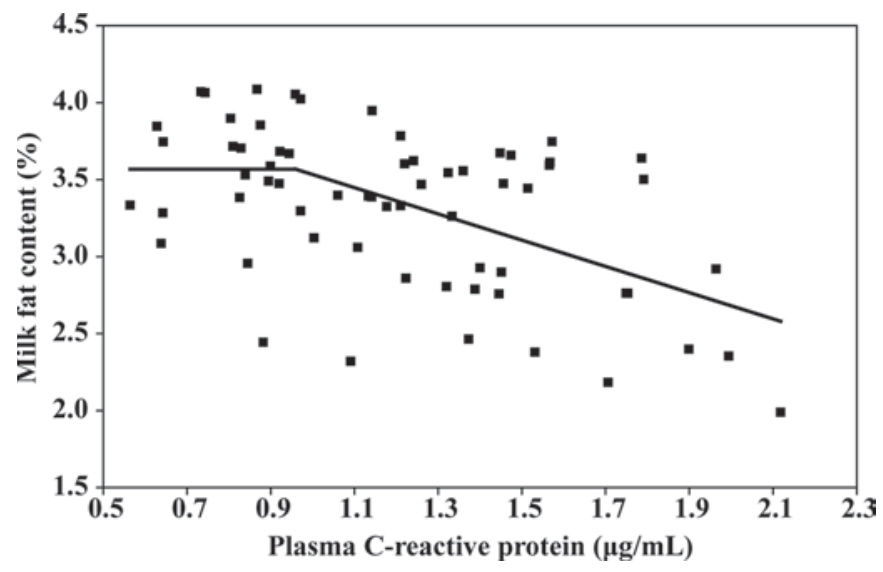

Figure 4. A straight-line, single break-point model fitted to milk fat content data $(y)$ in response to the concentration of plasma C-reactive protein $(\mathrm{CRP}, x)$ in dairy cows fed graded amounts of barley grain: $y=\mathrm{a}_{0}+\mathrm{b}_{1} \times x$, if $x>\mathrm{R}\left(\mathrm{a}_{0}=4.39, \mathrm{~b}_{1}=-0.853, \mathrm{R}\right.$ (break point) $=0.959 \mu \mathrm{g} / \mathrm{mL}$ plasma CRP, asymptotic plateau of $y=3.57 \%$ ); root mean square error $=0.45, \mathrm{R}^{2}=0.28, P<0.001, \mathrm{n}=64$. 

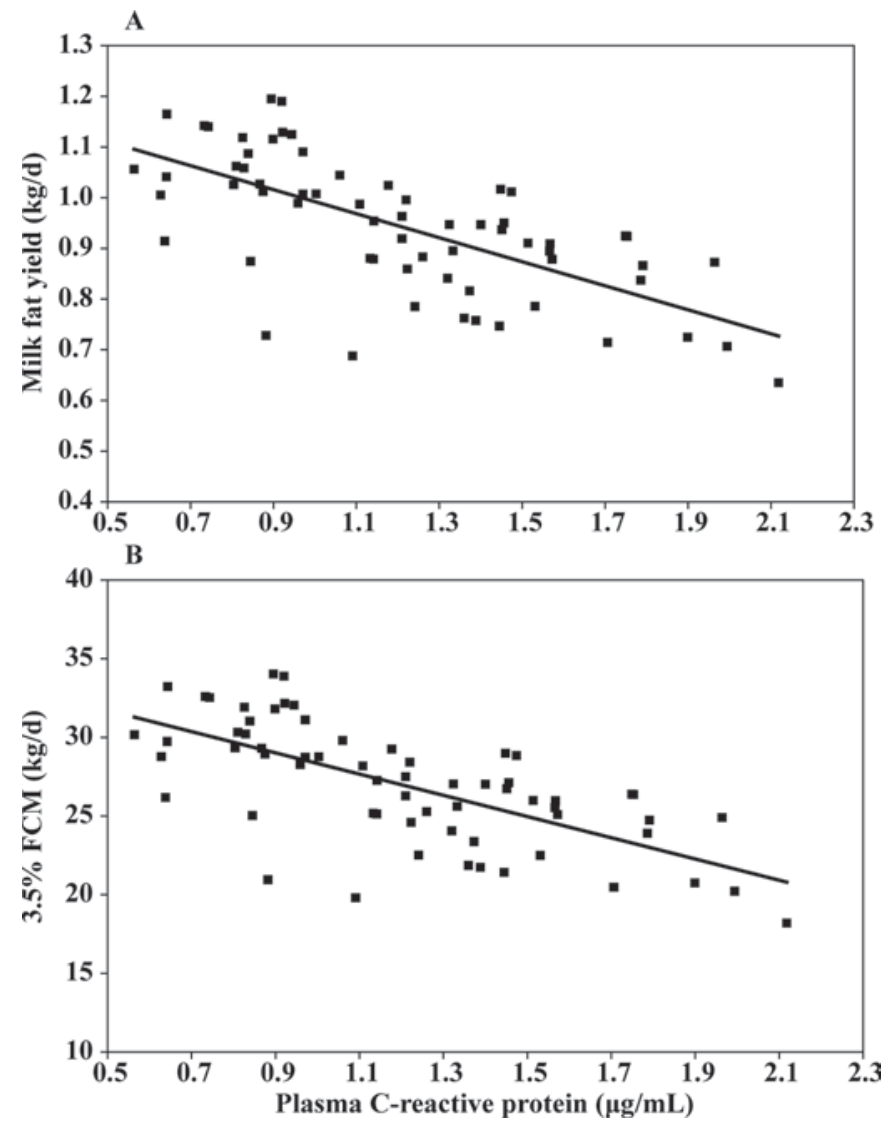

Figure 5. Best-fit linear models showing the relationship between milk fat yield (A) or 3.5\% FCM (B) data, both expressed as $y$, and concentration of plasma C-reactive protein $(\mathrm{CRP}, x)$ in dairy cows fed graded amounts of barley grain: A, $y=1.23-0.237 \times \mathrm{CRP}$, root mean square error $=0.10, \mathrm{R}^{2}=0.45, P<0.001, \mathrm{n}=64 ; \mathrm{B}, y=35.01$ $-6.743 \times \mathrm{CRP}$, root mean square error $=2.82, \mathrm{R}^{2}=0.46, P<0.001$, $\mathrm{n}=64$.

ing and can be attributed to the direct involvement of CRP in lipid and lipoprotein metabolism. Mounting evidence in human and animal studies suggests that infection and inflammation affect lipid and lipoprotein metabolism (Khovidhunkit et al., 2004). Different studies have indicated that administration of LPS affects both VLDL secretion and clearance according to the dose of LPS used. At a low dose, the VLDL secretion increased, whereas at a greater dose of LPS, the clearance rate of VLDL decreased (Feingold et al., 1992). The latter effect is related to the lowering of LPL activity in different tissues, including the mammary gland (Feingold et al., 1992). Interestingly, administration of LPS also increases plasma levels of CRP, and the latter is associated with VLDL (De Beer et al., 1982; Rowe et al., 1984). As we previously reported, plasma CRP increased in response to increasing rumen fluid LPS (Emmanuel et al., 2008). In the cow, VLDL are the primary source of blood TAG transferred into the mammary cells (Bauman and Griinari, 2001). About
$50 \%$ of the FA in ruminant milk TAG are derived from blood TAG (Bauman and Griinari, 2001). During lactation, there is a large increase in mammary tissue LPL activity with an accompanying decrease in LPL of adipose tissue (Herrera et al., 1988). The association of CRP with VLDL might be the host's mechanism to prevent the interaction of apoC-II with LPL during inflammatory states and lower clearance of TAG-rich lipoproteins such as VLDL to make more TAG available to the host. In fact, recent research has suggested that TAG-rich lipoproteins are necessary during conditions of metabolic endotoxemia because they bind LPS, protect against LPS-induced toxicity, and modulate the overall host response to this bacterial toxin (Barcia and Harris, 2005).

\section{Cows' Responses to Graded Amounts of Grain in the Diet}

In this article, we report a marked decrease in milk fat content and yield in response to increasing proportions of barley grain in the diet. This is in agreement with other research indicating $\mathrm{HC} / \mathrm{LF}$ diets lower milk fat content (Gaynor et al., 1995; Bauman and Griinari, 2001). Also, the study provides clear evidence that the feeding of high-grain diets lowers the efficiency and productivity of lactating dairy cows. Interestingly, although the increase in the proportion of barley grain in the diet was associated with greater milk yields, MEE in cows fed the largest amount of barley (i.e., $45 \%$ on DM basis) decreased by $26 \%$ compared with cows with no barley grain in the diet. It is interesting that attaining greater milk yields by feeding dairy cows higher proportions of cereal grains creates the impression of better energy efficiency of these diets. However, the results of this study clearly demonstrated that this assumption is not true, because high-grain diets decreased milk fat content and, consequently, the MEE of the cows.

Another interesting finding of this study was the high interindividual variation of the cows in response to highgrain diets. For example, cows responded differently for variables related to inflammatory response (i.e., rumen LPS and particularly plasma CRP), as well as those of milk and milk fat production, when they were challenged with increasing amounts of dietary grain. In fact, other researchers have previously reported high variation of the cows to an inflammatory insult such as after a systemic LPS challenge (Jacobsen et al., 2004). This is the first report to demonstrate different individual abilities of dairy cows to tolerate a challenge with high dietary grain, showing high variability in responses such as free rumen LPS and particularly plasma CRP. Interestingly, the high individual cow variation regarding rumen LPS and plasma CRP response was reflected by milk fat 
production data. Our findings are in agreement with data reported by Gaynor et al. (1995), who indicated different responses regarding milk fat content in dairy cows fed high amounts of concentrate in the diet.

Interestingly, the high interanimal variation with regard to CRP response (i.e., 54.4\%) found in this study agrees with recent reports and indicates the importance of genotype in production of CRP during inflammatory conditions (Danik and Ridker, 2007). Similarly, Elsasser et al. (2005) reported that the magnitude of plasma TNF- $\alpha$ response to an LPS challenge is genetically related.

Overall, our results emphasize the importance of taking the individual cow factor into account when investigating high grain-induced MFD. Elucidation of the mechanism(s) underlying interindividual variation in rumen LPS-mediated inflammatory responses and milk fat production in response to high dietary grain challenge may improve our understanding of the dietinduced MFD syndrome.

In conclusion, this investigation demonstrated that increasing proportions of barley grain in the diet were associated with a linear decrease in the milk fat content, milk yield, 3.5\% FCM, and MEE in dairy cows. The analysis of data revealed evidence of strong negative correlations among rumen LPS, plasma CRP, milk fat production, and MEE, implicating rumen LPSmediated inflammatory responses on the etiology of MFD syndrome and decreased MEE in lactating dairy cows. The study also showed different individual cow responses to the high dietary-grain challenge in terms of their rumen LPS, plasma CRP, and milk fat production. Further research is warranted to understand the underlying mechanism(s) of these relationships and increase our understanding of the biology of MFD to allow for more effective management strategies for its prevention in dairy cattle.

\section{ACKNOWLEDGMENTS}

We acknowledge the financial support from Alberta Milk (Edmonton, Alberta, Canada), Alberta Livestock Industry Development Fund (Edmonton, Alberta, Canada), and Natural Sciences and Engineering Research Council of Canada (Ottawa, Ontario, Canada). The assistance of D. G. V. Emmanuel, R. P. Pandian, and S. Sivaraman (University of Alberta, Edmonton, Alberta, Canada) with the sampling and laboratory analyses is highly appreciated. We also thank L. Doepel and A. Hayirli (University of Alberta, Edmonton, Alberta, Canada) for providing milk fat data. We are grateful to the technical staff at Dairy Research and Technology Center, University of Alberta, for their help and care with the cows.

\section{REFERENCES}

Amar, J., R. Burcelin, J. B. Ruidavets, P. D. Cani, J. Fauvel, M. C. Alessi, B. Chamontin, and J. Ferrieres. 2008. Energy intake is associated with endotoxemia in apparently healthy men. Am. J. Clin. Nutr. 87:1219-1223.

Ametaj, B. N., B. J. Bradford, G. Bobe, R. A. Nafikov, Y. Lu, J. W. Young, and D. C. Beitz. 2005. Strong relationships between mediators of the acute phase response and fatty liver in dairy cows. Can. J. Anim. Sci. 85:165-175.

Andersen, P. H. 2003. Bovine endotoxicosis: Some aspects of relevance to production diseases. Acta Vet. Scand. Suppl. 98:141-155.

Argilés, J. M., F. J. Lopez-Soriano, R. D. Evans, and D. H. Williamson. 1989. Interleukin-1 and lipid metabolism in the rat. Biochem. J. 259:673-678.

Barcia, A. M., and H. W. Harris. 2005. Triglyceride-rich lipoproteins as agents of innate immunity. Clin. Infect. Dis. 41(Suppl. 7):S498-S503.

Bauman, D. E., and J. M. Griinari. 2001. Regulation and nutritional manipulation of milk fat: Low-fat milk syndrome. Livest. Prod. Sci. 70:15-29.

Bauman, D. E., J. W. Perfield II, K. J. Harvatine, and L. H. Baumgard. 2008. Regulation of fat synthesis by conjugated linoleic acid: Lactation and the ruminant model. J. Nutr. 138:403-409.

Canadian Council on Animal Care. 1993. Guide to the Care and Use of Experimental Animals. Vol. 1. 2nd ed. Canadian Council on Animal Care, Ottawa, Canada.

Cani, P. D., J. Amar, M. A. Iglesias, M. Poggi, C. Knauf, D. Bastelica, A. M. Neyrinck, F. Fava, K. M. Tuohy, C. Chabo, A. Waget, E. Delmee, B. Cousin, T. Sulpice, B. Chamontin, J. Ferrieres, J.-F. Tanti, G. R. Gibson, L. Casteilla, N. M. Delzenne, M. C. Alessi, and R. Burcelin. 2007. Metabolic endotoxemia initiates obesity and insulin resistance. Diabetes 56:1761-1772.

Danik, J. S., and P. M. Ridker. 2007. Genetic determinants of C-reactive protein. Curr. Atheroscler. Rep. 9:195-203.

Davis, C. L., and R. E. Brown. 1970. Low-fat milk syndrome. Pages 545-565 in Physiology of Digestion and Metabolism in the Ruminant. A. T. Phillipson, ed. Oriel Press, Newcastle upon Tyne, UK.

De Beer, F. C., A. K. Soutar, M. L. Baltz, I. M. Trayner, A. Feinstein, and M. B. Pepys. 1982. Low density lipoprotein and very low density lipoprotein are selectively bound by aggregated C-reactive protein. J. Exp. Med. 156:230-242.

Elsasser, T. H., J. W. Blum, and S. Kahl. 2005. Characterization of calves exhibiting a novel inherited TNF- $\alpha$ hyper-responsiveness to endotoxin: Associations with increased pathophysiological complications. J. Appl. Physiol. 98:2045-2055.

Emmanuel, D. G., S. M. Dunn, and B. N. Ametaj. 2008. Feeding high proportions of barley grain stimulates an inflammatory response in dairy cows. J. Dairy Sci. 91:606-614.

Emmanuel, D. G., K. L. Madsen, T. A. Churchill, S. M. Dunn, and B. N. Ametaj. 2007. Acidosis and lipopolysaccharide from Escherichia coli B:055 cause hyperpermeability of rumen and colon tissues. J. Dairy Sci. 90:5552-5557.

Evans, R. D., and D. H. Williamson. 1988. Tumour necrosis factor alpha (cachectin) mimics some of the effects of tumour growth on the disposal of a [14C]lipid load in virgin, lactating and litterremoved rats. Biochem. J. 256:1055-1058.

Feingold, K. R., I. Staprans, R. A. Memon, A. H. Moser, J. K. Shigenaga, W. Doerrler, C. Dinarello, and C. Grunfeld. 1992. Endotoxin rapidly induces changes in lipid metabolism that produce hypertriglyceridemia: Low doses stimulate hepatic triglyceride production while high doses inhibit clearance. J. Lipid Res. 33:1765-1776.

Gaynor, P. J., D. R. Waldo, A. V. Capuco, R. A. Erdman, L. W. Douglass, and B. B. Teter. 1995. Milk fat depression, the glucogenic theory, and trans-C $\mathrm{C}_{18: 1}$ fatty acids. J. Dairy Sci. 78:2008-2015.

Ghoshal, S., J. Witta, J. Zhong, W. de Villiers, and E. Eckhardt. 2009. Chylomicrons promote intestinal absorption of lipopolysaccharides. J. Lipid Res. 50:90-97.

Gozho, G. N., D. O. Krause, and J. C. Plaizier. 2007. Ruminal lipopolysaccharide concentration and inflammatory response 
during grain-induced subacute ruminal acidosis in dairy cows. J. Dairy Sci. 90:856-866.

Herrera, E., M. A. Lasunción, D. Gomez-Coronado, P. Aranda, P. López-Luna, and I. Maier. 1988. Role of lipoprotein lipase activity on lipoprotein metabolism and the fate of circulating triglycerides in pregnancy. Am. J. Obstet. Gynecol. 158:1575-1583.

Jacobsen, S., P. H. Andersen, T. Toelboell, and P. M. Heegaard. 2004. Dose dependency and individual variability of the lipopolysaccharide-induced bovine acute phase protein response. J. Dairy Sci. 87:3330-3339.

Khafipour, E., D. O. Krause, and J. C. Plaizier. 2009. A grainbased subacute ruminal acidosis challenge causes translocation of lipopolysaccharide and triggers inflammation. J. Dairy Sci. 92:1060-1070.

Khovidhunkit, W., M. S. Kim, R. A. Memon, J. K. Shigenaga, A. H. Moser, K. R. Feingold, and C. Grunfeld. 2004. Effects of infection and inflammation on lipid and lipoprotein metabolism: Mechanisms and consequences to the host. J. Lipid Res. 45:1169-1196.

Krause, D. O., W. J. Smith, L. L. Conlan, J. M. Gough, M. A. Williamson, and C. S. McSweeney. 2003. Diet influences the ecology of lactic acid bacteria and Escherichia coli along the digestive tract of cattle: Neural networks and 16S rDNA. Microbiology 149:5765.

López-Soriano, F. J., and D. H. Williamson. 1994. Acute effects of endotoxin (lipopolysaccharide) on tissue lipid metabolism in the lactating rat. The role of delivery of intestinal glucose. Mol. Cell. Biochem. 141:113-120.

Merkel, M., R. H. Eckel, and I. J. Goldberg. 2002. Lipoprotein lipase: Genetics, lipid uptake, and regulation. J. Lipid Res. 43:19972006 .
Neal, M. D., C. Leaphart, R. Levy, J. Prince, T. R. Billiar, S. Watkins, J. Li, S. Cetin, H. Ford, A. Schreiber, and D. J. Hackam. 2006. Enterocyte TLR4 mediates phagocytosis and translocation of bacteria across the intestinal barrier. J. Immunol. 176:30703079 .

NRC. 2001. Nutrient Requirements of Dairy Cattle. 7th rev. ed. Natl. Acad. Sci., Washington, DC.

Pekala, P. H., M. Kawakami, C. W. Angus, M. D. Lane, and A. Cerami. 1983. Selective inhibition of synthesis of enzymes for de novo fatty acid biosynthesis by an endotoxin-induced mediator from exudate cells. Proc. Natl. Acad. Sci. USA 80:2743-2747.

Piperova, L. S., U. Moallem, B. B. Teter, J. Sampugna, M. P. Yurawecz, K. M. Morehouse, D. Luchini, and R. A. Erdman. 2004. Changes in milk fat in response to dietary supplementation with calcium salts of trans-18:1 or conjugated linoleic fatty acids in lactating dairy cows. J. Dairy Sci. 87:3836-3844.

Robbins, K. R., A. M. Saxton, and L. L. Southern. 2006. Estimation of nutrient requirements using broken-line regression analysis. J. Anim. Sci. 84(E. Suppl.):E155-E165.

Rowe, I. F., A. K. Soutar, I. M. Trayner, G. R. Thompsont, and M. B. Pepys. 1984. Circulating human C-reactive protein binds very low density lipoproteins. Clin. Exp. Immunol. 58:237-244.

Shuster, D. E., R. J. Harmon, J. A. Jackson, and R. W. Hemken. 1991. Endotoxin mastitis in cows milked four times daily. J. Dairy Sci. $74: 1527-1538$

Sweet, M. J., and D. A. Hume. 1996. Endotoxin signal transduction in macrophages. J. Leukoc. Biol. 60:8-26. 